\title{
Development and Characterization of PCR Markers in Cucumber
}

\author{
Gennaro Fazio, ${ }^{1}$ Jack E. Staub, ${ }^{2}$ and Sang Min Chung \\ U.S. Department of Agriculture, Agricultural Research Service, Vegetable Crops Unit, Department of \\ Horticulture, 1575 Linden Drive, University of Wisconsin, Madison, WI 53706
}

\begin{abstract}
AdDitional INDEX WORDS. simple sequence repeats, SSR, sequence characterized amplified regions, SCAR, single nucleotide polymorphisms, SNP, marker optimization

AbSTRact. Highly polymorphic microsatellites or simple sequence repeat (SSR), along with sequence characterized amplified region (SCAR) and single nucleotide polymorphisms (SNP), markers are reliable, cost-effective, and amenable for large scale analyses. Molecular polymorhisms are relatively rare in cucumber (Cucumis sativus $\mathbf{L}$.) (3\% to 8\%). Therefore, experiments were designed to develop SSR, SCAR and SNP markers, and optimize reaction conditions for PCR. A set of 110 SSR markers was constructed using a unique, strategically applied methodology that included the GeneTrapper (Life Technologies, Gaithersburg, Md.) kit to select plasmids harboring microsatellites. Of these markers, $58(52 \%)$ contained dinucleotide repeats (CT, CA, TA), 21 (19\%) possessed trinucleotide repeats (CTT, ATT, ACC, GCA), $3(2.7 \%)$ contained tetranucleotide repeats (TGCG, TTAA, TAAA), 4 (3.6\%) enclosed pentanucleotide repeat (ATTTT, GTTTT, GGGTC, AGCCC), $3(2.7 \%)$ contained hexanucleotide repeats (CCCAAA, TAAAAA, GCTGGC) and 21 possessed composite repeats. Four SCARs (L18-3 SCAR, AT1-2 SCAR, N6-A SCAR, and N6-B SCAR) and two PCR markers based on SNPs (L18-2H19 A and B) that are tightly linked to multiple lateral branching (i.e., a yield component) were also developed. The SNP markers were developed from otherwise monomorphic SCAR markers, producing genetically variable amplicons. The markers L18-3 SCAR and AT1-2 SCAR were codominant. A three-primer strategy was devised to develop a codominant SCAR from a sequence containing a transposable element, and a new codominant SCAR product was detected by annealing temperature gradient (ATG) PCR. The use of a marker among laboratories can be enhanced by methodological optimization of the PCR. The utility of the primers developed was optimized by ATG-PCR to increase reliability and facilitate technology transfer. This array of markers substantially increases the pool of genetic markers available for genetic investigation in Cucumis.
\end{abstract}

Since the advent of the polymerase chain reaction (PCR) (Saiki et al., 1988), many techniques have been developed to detect DNA polymorphisms. Such polymorphisms have utility in plant genetics and breeding (Gupta and Varshney, 2000; Knapp 1998; Lee, 1995; Staub et al., 1996c). DNA fragment and sequence analysis has been used for genetic mapping experiments (Bradeen et al., 2001; Tanksley and Nelson, 1996), diversity analysis (Horejsi and Staub, 1999), and more recently markerassisted selection in many crop species (Quarrie, 1996; Romagosa et al., 1999; Shen et al., 2001; Yousef and Juvik, 2001). For instance, isozymes, random amplified polymorphic DNA (RAPD) and restriction fragment polymorphisms (RFLP) have been used in cucumber (Cucumis sativus) for genetic mapping and diversity analysis (Dijkhuizen et al., 1996; Horejsi et al., 2000; Kennard et al., 1994; Meglic and Staub, 1996a; Meglic and Staub, 1996b; Serquen et al., 1997). The use of these markers has been limited due to the narrow genetic base (3\% to $8 \%$ on a per band basis) of cucumber (Horejsi and Staub, 1999; Knerr et al., 1989). A higher level of polymorphism has been documented in $C$. sativus, and in Cucurbita and Citrullus species of the Cucurbitaceae using simple sequence repeats (SSR) (Katzir et al., 1996). Four of the seven SSRs used detected polymorphisms among the 11 cucumber genotypes examined which allowed for the calculation of gene diversity values ranging between 0.18 and 0.64 (Katzir et al.,

Received for publication 23 Jan. 2002. Accepted for publication 17 Apr. 2002. Mention of a trade name, proprietary product, or specific equipment does not constitute a guarantee or warranty by the USDA and does not imply its approval to the exclusion of other products that may be suitable. This research was partially supported by grant IS-2708-96 from the U.S.-Israel Binational Agricultural Research and Development (BARD) fund.

${ }^{1}$ Graduate student, currently USDA-ARS, Curator, Plant Genetics Research Unit, Geneva, NY 14456.

${ }^{2}$ To whom reprint requests should be addressed.
1996). More recently, 20 polymorphic SSRs were developed and tested in cucumber to more critically determine their potential value for genetic analysis. Polymorphisms were detected at 12 of the 20 SSR loci (60\%) having two to five alleles at each SSR locus examined (Danin Poleg et al., 2000; Danin Poleg et al., 2001).

A moderately large molecular marker database now exists for cucumber that includes isozymes (Meglic and Staub, 1996b), RFLP(Dijkhuizen et al., 1996), RAPD (Horejsi and Staub, 1999), amplified fragment length polymorphisms (AFLP) (Bradeen et al., 2001), SSR (Danin Poleg et al., 2000), and sequence characterized amplified regions (SCAR) (Horejsi et al., 1999) markers. The application of these markers for diversity assessment has allowed for the partitioning of commercial germplasm into market classes, and the grouping of accessions in the U.S. National Plant Germplasm System into geographic proximity and country of origin. Their limitations for use in legal applications stems from their paucity, degree of consistency, and cost (Staub, 1999; Staub et al., 1996b; Staub and Meglic, 1993).

The characterization of additional polymorphic SSR, single nucleotide polymorphisms (SNP), and SCAR markers would allow increased precision in genetic similarity estimation among cucumber cultivars as well as in the mapping of qualitative and quantitative traits. Despite their high development costs, microsatellites have played an important role in genetic studies of higher eukaryotes, such as sweetpotato (Ipomoea batatas L. Lam.) (Buteler et al., 1999), cassava (Manihot esculenta L.) (Chavarriagaaguirre et al., 1998), peach (Prunus persica L.) (Cipriani et al., 1999), barley (Hordeum vulgare L.) (Donini et al., 1998), and beans (Phaseolus vulgaris L.) (Yu et al., 1999). Where SSR size polymorphisms can be resolved by high throughput and inexpensive technologies (e.g., agarose gel analysis), their codominant nature, and relatively high polymorphism rate make them amenable for many types genomic analyses (Donini et al., 1998; 
Gupta et al., 1999). Likewise, the conversion of a RAPD marker to SCAR or SNP markers can enhance the marker's repeatability (Michelmore et al., 1991; Staub et al., 1996a).

The initial development of microsatellite markers requires the characterization of sequences flanking the repeat motif followed by the design of flanking PCR primers. Several methods have been devised for the initial characterization of the flanking sequences (Gupta and Varshney, 2000) including the use of a published gene sequence (Litt and Luty, 1989), database searches (Danin Poleg et al., 2000; Danin Poleg et al., 2001; Katzir et al., 1996), the construction of genomic or cDNA libraries with subsequent screening with labeled oligonucleotide probes (Bryan et al., 1997; Dayanandan et al., 1998; Huang et al., 1998; Roder et al., 1998), the construction of microsatellite-enriched libraries followed by PCR screening (Fischer and Bachmann, 1998), hybridization of biotinylated oligonucleotides to single stranded M13 libraries (Paetkau, 1999), and the use of bacterial artificial chromosome (BAC) libraries to target specific genomic regions (Cregan et al., 1999). The development of SSR marker technology for cucumber is a necessary step to increase map saturation for a more complete analysis of its genome and the application of this information for its improvement. A method for the discovery of microsatellites and their flanking sequences is described herein along with the identification of 2 SNP markers and the development of 110 microsatellite and 4 SCAR markers and their optimization in the PCR.

\section{Materials and Methods}

\section{SSR marker development}

The development of SSR markers (Fig. 1) involved the construction of a cucumber DNA genomic library, and subsequent capture of library inserts aided by GeneTrapper technology, followed by the sequencing of captured products (Fazio and Staub, 2000; Fazio, 2001). Sequence information was then used to develop primer pairs, which flanked target SSR regions.

DNA EXTRACTION, RESTRICTION AND SIZE FRACTIONATION. Genomic DNA from cucumber line GY7 (released by the University of Wisconsin, 1996, R.L. Lower; evaluated as experimental line G421) was extracted from young leaves (1 to $15 \mathrm{~cm}^{2}$ ) and apical meristems according to a nuclear DNA extraction protocol (Sambrook et al., 1989). Extraction products were treated with RNAse ONE (Promega, Madison, Wis.). Recovered DNA was quantified using a TKO 100 fluorometer (Hoefer Scientific Instruments, San Francisco, Calif.). In separate reactions, $100 \mathrm{mg}$ of DNA was restricted using EcoR I* restriction enzyme (Promega) and Acs I (Roche, Indianapolis, Ind.), which recognizes the sequence (A or G)/AATT(T or C), and creates compatible ends with $E c o$ R I restriction site. The star activity in $E c o$ R I was initiated by adding $10 \%$ DMSO to the restriction buffer (Ander- son and McDonald, 1993; Robinson and Sligar, 1995). This activity generated additional restriction fragments ranging 200 to $1300 \mathrm{bp}$ as opposed to EcoR I normal activity.

Since the then available sequencing techniques could only resolve $\approx 800 \mathrm{bp}$, fragment sizes between 200 to $1300 \mathrm{bp}$ were needed to avoid unnecessary subcloning and to simplify the sequencing process. Restricted DNA was size-fractionated using a low pressure, $75-\mathrm{cm}$-long, 16-mm-diameter, chromatography column (Fisher Scientific, Pittsburg, Pa.) filled with Sephacryl S500 (Pharmacia, Peapack, N.J.). The column was packed according to manufacturer's specifications for Sephacryl S-500 and equilibrated with $200 \mathrm{~mL}$ elution buffer ( 0.1 м Tris-HCL pH 8.0, $0.15 \mathrm{M} \mathrm{NaCl}, 0.001 \mathrm{M}$ EDTA) at $0.3 \mathrm{~mL} \cdot \mathrm{min}^{-1}$ before fractionation. Both samples (EcoR I* and Acs I) of restricted DNA were fractionated $\left(0.3 \mathrm{~mL} \cdot \mathrm{min}^{-1}\right)$ separately, and eluted DNA was collected in 75 2-mL aliquots. Eluted DNA was precipitated, washed and resuspended in TE. Fragments from eluted aliquots of both restrictions were then sized by agarose gel electrophoresis

Fig. 1. Methodology for the development of cucumber simple sequence repeat (SSR) markers using the GeneTrapper kit (Life Technologies, Gaithersburg, Md.).

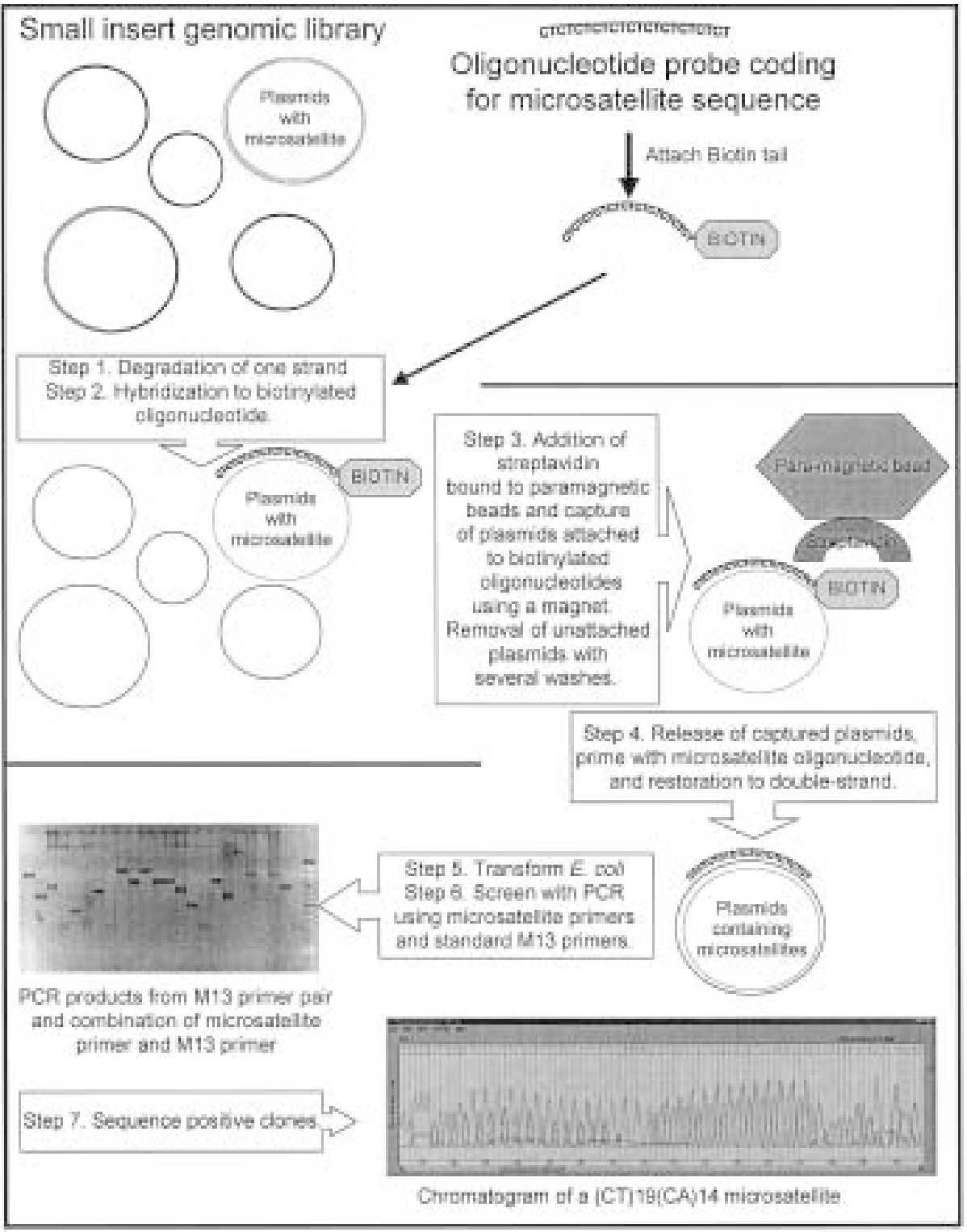


and simultaneously compared to the nonfractionated digestion products from each restriction. Fractions between 200 to $1200 \mathrm{bp}$ were chosen to create a small insert genomic library, and then they were combined for ligation to a vector. These size fractions were chosen because of the increased difficulty of sequencing larger size inserts.

LiBRARY CONSTRUCTION, MASS EXCISION, AND PLASMID DNA EXTRACTION. Fractionated DNA was ligated to Lambda Ziplox EcoR I arms (Life Technologies, Gaithersburg, Md.), and then it was packaged in a lambda vector with Gigapack III Gold packaging extract (Stratagene, La Jolla, Calif.). The resulting library was titered and packaging efficiency was determined by blue-white colony screening following the manufacturer's specifications.

Primary Ziplox libraries were mass excised in vivo into the plasmid vector, pZL1 (Life Technologies) in the strain of E. Coli DH10B Zip (Life Technologies) as per manufacturer's recommendation. The mass excision of the lambda vector into a plasmid and the expansion of the plasmid library were performed simultaneously in a semi-solid medium according to the manufacturer to minimize representational biases (some cell lines dividing faster than others) that can occur during colony expansion in liquid media. The growth media was prepared by adding $1.35 \mathrm{~g}$ of SeaPrep agarose (FMC Bioproducts, Rockland, Maine) to 500 $\mathrm{mL}$ of $2 \times \mathrm{LB}$ in an autoclavable bottle using a stir plate to avoid the formation of agarose clumps. The bottle was autoclaved for 30 min and cooled in a water bath until the media reached $37^{\circ} \mathrm{C}$. Ampicillin (Fisher) was then added to the media $\left(150 \mathrm{mg} \cdot \mathrm{L}^{-1}\right)$ and $5 \times 10^{5}$ primary transformants from the ZipLox libraries were added to the bottle while being stirred. The bottle was subsequently placed in a $0{ }^{\circ} \mathrm{C}$ water bath for $1 \mathrm{~h}$ to solidify the media. The culture was incubated undisturbed at $30^{\circ} \mathrm{C}$ for $45 \mathrm{~h}$, and then centrifuged at $3000 g_{\mathrm{n}}$ for $20 \mathrm{~min}$. The supernatant was discarded, and the recovered cells were resuspended in $100 \mathrm{~mL}$ of $2 \times \mathrm{LB}$ Glycerol (12.5\%). Subsequently, $100 \mathrm{~mL}$ of LB media were inoculated with $2.5 \times 10^{9}$ cells resulting from the mass excision, and the mixture was then cultured at $30{ }^{\circ} \mathrm{C}$ until the culture reached an OD of 0.8. Plasmid DNA to be used in the GeneTrapper protocol was extracted by with the plasmid Maxi-Prep Kit procedure (Qiagen, Valencia, Calif.).

CAPTURE OF PLASMIDS CONTAINING MICROSATELlites. In preparation for the GeneTrapper (Life Technologies) reaction, five oligonucleotides (20 to $30 \mathrm{bp}$ ) homologous for common microsatellite motifs $\left[(\mathrm{CT})_{12},(\mathrm{TG})_{12},(\mathrm{CTT})_{9},(\mathrm{TCC})_{9},(\mathrm{ATT})_{9}\right]$ were modified at the 3 ' end by the addition of biotin (biotin-14dCTP) with a terminal transferase enzyme provided with the GeneTrapper kit. Addition of the biotin to the oligonucleotides was verified by electrophoretic analysis of the products on a $15 \times$ $17 \times 0.7 \mathrm{~cm}$-thick $16 \%$ (w/v) 19 acrylamide : 1 bisacrylamide gel, containing $8 \mathrm{M}$ urea, and $1 \times \mathrm{TBE}$ buffer, for $1.5 \mathrm{~h}$ at $400 \mathrm{~V}$. The gel was stained in an ethidium bromide solution $\left(0.5 \mathrm{mg} \cdot \mathrm{L}^{-1}\right)$ for $15 \mathrm{~min}$. Reaction products were visualized using the Dark Reader transilluminator system (Clare Chemical, Denver, Colo.). Technical protocols for use of GeneTrapper technology are summarized below as steps 1 through 7 and in Fig. 1 .

1) Plasmid DNA from the cucumber genomic library was treated with Gene II protein and Exonuclease III to obtain singlestranded circular plasmid DNA. The products from the GeneII and Exonuclease III treatments and the untreated plasmid DNA were electrophoresed on a $0.7 \%$ agarose gel stained with ethidium bromide $\left(0.5 \mu \mathrm{g} \cdot \mathrm{mL}^{-1}\right)$ to verify the formation of single-stranded plasmid DNA.

2) Single-stranded DNA was then separately hybridized to each of the biotinylated oligonucleotides. GeneII/ExonucleaseIIItreated DNA was added to a solution containing hybridization buffer, and then subsequently denatured at $95^{\circ} \mathrm{C}$ for $1 \mathrm{~min}$ and chilled on ice for $1 \mathrm{~min}$. Then a $1-\mu \mathrm{L}$ aliquot of the biotinylated oligonucleotide $\left(20 \mathrm{ng} \cdot \mu \mathrm{L}^{-1}\right)$ was added to the denatured DNA and incubated for $1 \mathrm{~h}$ at $37^{\circ} \mathrm{C}$.

3) Streptavidin bound to paramagnetic beads was used to capture the microsatellite containing single-stranded plasmid molecules from Step 2. The hybridization mixture was incubated with a streptavidin bead suspension for $30 \mathrm{~min}$ at $37^{\circ} \mathrm{C}$ with gentle mixing. The streptavidin beads were then separated from the reaction by means of a microcentrifuge tube rack fitted with a magnet. The capture products were washed four times to eliminate any unbound single-stranded DNA or intact plasmid DNA.

4) The captured product was then treated with elution buffer to release the captured single-stranded (SS) DNA from the streptavidin-bound biotin (Step 3). The SS DNA was coprecipitated in the presence of glycogen by the addition of $7.5 \mathrm{M}$ $\mathrm{NH}_{4} \mathrm{Oac}$ and $100 \%$ ethanol, and immediately centrifuged at 4 ${ }^{\circ} \mathrm{C}\left(14,000 g_{\mathrm{n}}\right)$ for $30 \mathrm{~min}$. The SS DNA was subsequently repaired to form double-stranded DNA by adding $50 \mathrm{ng}$ of unbiotinylated capture oligonucleotide to a mixture containing a repair enzyme, a dNTP mix (1 mM), captured SS DNA, and $10 \times$ reaction buffer. This reaction mixture was incubated initially at $90{ }^{\circ} \mathrm{C}$ for $1 \mathrm{~min}$, then at $55^{\circ} \mathrm{C}$ for $30 \mathrm{~s}$, and lastly at $70{ }^{\circ} \mathrm{C}$ for $15 \mathrm{~min}$.

5) The resultant double-stranded plasmids (Step 4) were used to transform DH10B E. coli by standard electroporation. A CellPorator system was used in conjunction with the Cell-Porator voltage booster (Life Technologies) $(0.15 \mathrm{~cm}$ gap chamber; $400 \mathrm{~V}$; $330 \mathrm{mF}$; low ohms; fast charge rate; voltage booster resistance 4,000 ohms) to transform $23 \mu \mathrm{L}$ of ElectroMAX DH10B cells mixed with $2 \mathrm{~mL}$ of the double-stranded repaired capture reaction products (Step 4). Initially, electroporated products were rescued by incubation in $1 \mathrm{~mL}$ SOC. media at $37^{\circ} \mathrm{C}$ for $1 \mathrm{~h}$. In subsequent captures, the transformations were incubated for only 25 min to reduce the amount of duplication in the captured products. The rescued products were plated onto ampicillin $\left(150 \mu \mathrm{g} \cdot \mathrm{mL}^{-1}\right) \mathrm{LB}$ agar selection media and incubated for $8 \mathrm{~h}$ at $37^{\circ} \mathrm{C}$. Theoretically, only E. coli harboring the intact pZL1 (putatively containing a microsatellite region) derived from the cucumber DNA library survived the selection media challenge.

6) Single colonies were picked, named sequentially, and used to inoculate $3 \mathrm{~mL}$ of LB Ampicillin $\left(100 \mu \mathrm{g} \cdot \mathrm{mL}^{-1}\right)$. The inoculated media was incubated at $37{ }^{\circ} \mathrm{C}$ overnight, and then plasmid DNA were extracted using the QIAPREP miniprep kit (Qiagen) according to the manufacturer's protocol. Plasmid DNA was amplified by PCR [ $3 \mathrm{~mm} \mathrm{MgCl}, 0.2 \mathrm{~mm} \mathrm{dNTPs,}$ 15 to $20 \mathrm{ng}$ of DNA, $0.4 \mathrm{~mm}$ of each primer, Taq polymerase (3 units) and commercial $10 \times$ buffer (Promega)] containing the capture oligonucleotide along with the standard forward or reverse M13 primer to confirm the presence of a microsatellite in the plasmid.

7) Plasmid DNA (Step 5) (4 $\mu \mathrm{L}$ at $\left.200 \mathrm{ng} \cdot \mathrm{mL}^{-1}\right)$ from positive clones was added to a $16-\mu \mathrm{L}$ sequencing reaction mixture containing $4 \mu \mathrm{L}$ of $2.5 \times$ reaction buffer $[5 \times$ is $400 \mathrm{~mm}$ Tris $\mathrm{pH}$ 9, $10 \mathrm{~mm} \mathrm{MgCl}$ ], $4 \mu \mathrm{L}$ of BigDye enzyme mix (Applied Biosystems, Foster City, Calif.), $1 \mathrm{~mL}$ of M13 forward or reverse primer $\left(20 \mathrm{pmol} \cdot \mu \mathrm{L}^{-1}\right)$, and $7 \mu \mathrm{L}$ of distilled water. Sequencing reactions were run on a thermal cycler (9700; 
Perkin-Elmer, Boston, Mass.) $\left(45\right.$ cycles of $95^{\circ} \mathrm{C} 20 \mathrm{~s}, 55^{\circ} 30$ $\mathrm{s}, 60^{\circ} 4 \mathrm{~min}$, and then $72^{\circ} 7 \mathrm{~min}$ ). Subsequently dye terminators were removed using MicroBioSpin columns (BioRad, Hercules, Calif.). The sequencing reaction products were resolved using a sequencer (ABI 377; Perkin Elmer).

These steps were repeated in five different experiments with different biotinylated oligonucleotides. The results of the biotinylated (CT)12 oligonucleotide capture procedure is reported herein.

SEquence ANALYSIS AND PRIMER DESIGN. All sequences from the capture were analyzed and compared to each other using the assembly feature provided in the GeneTool 1.0 software package (Biotools, Edmonton, Canada). This allowed for the elimination of duplicates and identification of overlapping DNA regions. The resulting unique sequences were then entered into the primer design software OLIGO 6.0 (Life Science Software, Long Lake, Minn.). Initially, no restrictions were placed on the size of the oligonucleotides to be constructed, and thus the size of the oligonucleotides in any specific primer pair was determined by closely matching the Tm (melting temperature) of each primer in the pair. This construction strategy sometimes resulted in primers 14 to $16 \mathrm{bp}$ in length, which were not amenable to infrared analysis protocols using the fluorescent M13 tailed primers technique (Oetting et al., 1995 ) then being implemented in some laboratories. Therefore, all subsequent primers were designed to have a minimum of $24 \mathrm{bp}$ in length, be hairpin and duplex free, while possessing the possibility of a 3' GC clamp and no false priming sites. Although these general guidelines were followed in the main, in certain cases the flanking sequences available did not meet all the guideline prerequisites requiring a relaxation of the acceptance criteria.

\section{Development single nucleotide polymorphism (SNP) and characterized sequence (SCAR) markers}

Two inbred lines, G421 and H-19 (University of ArkansasFayetteville, 1993) used in a previous cucumber genetic mapping project (Serquen et al., 1997) were used as sources for template DNA in PCR to identify single nucleotide polymorphisms and/or polymorphisms caused by insertion/deletions (Indel) within SCAR markers (agarose analysis) monomorphic between G-421 and H19. These markers were selected because of their potential usefulness in current mapping projects.

Two putative loci (L-18-2-SCAR, and N6-SCAR) were amplified using SCAR primers in both of the mapping inbred lines and two loci (RAPD L-18-3, AT1-2) were amplified with RAPD primers L-18 and AT-1 (Operon Technologies, Alameda, Calif.). L18-2-SCAR, was monomorphic between G421 and H19 lines and N6-SCAR amplified bands of different sizes in H-19 and G-421 suggesting the possibility of a codominant genetic nature. Further analysis revealed that N6-SCAR marker under standard PCR conditions failed to amplify the higher molecular weight band in the $F_{1}$ hybrid as well as in the heterozygotes in an $F_{2}$ population thus making this potentially codominant marker behave as a dominant one. Because of these attributes, experiments were designed to improve the performance of those markers.

Amplicons were separated on a $1.6 \%$ agarose gel (Life Technologies) and stained with ethidium bromide $\left(0.5 \mu \mathrm{g} \cdot \mathrm{mL}^{-1}\right)$. Banding patterns were visualized using a Dark Reader transilluminator, which does not use UV light, and therefore does not damage the DNA during visualization ultimately increasing transformation efficiency during subsequent cloning procedures. DNA bands were cut out of the gel and extracted using the Qiagen Gel Extraction Kit (Qiagen). The protocol from the pGEM-T Easy Vector System II cloning kit (Promega) was followed to ligate PCR products into the pGEM-T vector and transform competent JM109 E. coli cells with the ligated vector-insert. Plasmid DNA of colonies with positive insertional events identified by blue-white visual screening were extracted, and then sequenced using the same methods described in the previous section (Fig. 1, Step 7, microsatellite capture). Likewise, sequence analysis and primer design were performed using software and procedures previously described. However, in this case sequences of each marker band from line $\mathrm{H}-19$ were compared to corresponding band sequences in G421 to identify mismatch polymorphisms (SNPs) and insertion-deletion (Indel) polymorphisms. Sequence comparison information was then used strategically to design SNP and SCAR primers.

\section{Optimization and customization of primer-pair-specific PCR conditions}

An optimal PCR primer-pair design for amplification of specific DNA can be predicted by computer driven formulae and algorithms (Breslauer et al., 1986; Freier et al., 1986; Rychlik and Rhoads, 1989; Rychlik et al., 1990). Factors considered by these programs include 1) primer melting temperature (Tm), 2) product melting temperature, 3) primer sequence uniqueness with respect to the source sequence, 4) primer GC content, and, 5) 3' end GC base anchor motif. However, such calculated properties often do not coincide with the information obtained from empirical assessment of primer-pair product performance obtained under different reaction conditions. Thus, PCR optimization of primer pairs designed to amplify SSRs, SNPs, and SCAR markers was performed by subjecting such primers to annealing temperature gradient PCR (ATGPCR). Temperature gradient PCR amplifications were performed in a Eppendorf Master Cycler (Eppendorf, Hamburg, Germany) having a standard 12 column ( 1 to 12$) \times 8$ rows (A to $\mathrm{H}$ ) microtiter format providing row-dependent response information across rows (i.e., 12 temperatures in each column). The PCR reactions were performed in $15-\mu \mathrm{L}$ volumes of PCR mix [ $3 \mathrm{~mm} \mathrm{MgCl}, 0.2 \mathrm{~mm}$ dNTPs, 15 to $20 \mathrm{ng}$ of DNA, 0.4 mm of each primer, 2 units of Taq DNA polymerase and 10×commercial buffer(Promega)] overlayed with $10 \mu \mathrm{L}$ of light weight mineral oil (Fisher). The ATG-PCR cycling conditions were conducted in split-well plates (Robbins Scientific, Sunnyvale, Calif.) as follows. A melting step $\left(94^{\circ} \mathrm{C}\right.$ for $3 \mathrm{~min}$ ), $40 \mathrm{PCR}$ cycles $\left(30 \mathrm{~s}\right.$ at $94^{\circ} \mathrm{C}, 1 \mathrm{~min}$ gradient annealing step 45 to $65^{\circ} \mathrm{C}$, and $90 \mathrm{~s}$ at $72{ }^{\circ} \mathrm{C}$ ), and an elongation step ( $7 \mathrm{~min}$ at 72 $\left.{ }^{\circ} \mathrm{C}\right)$.

Initially, DNA from H-19 and G-421 was used to detect locusspecific polymorphisms. A PCR master mix was initially prepared without DNA or primer, and then divided into two aliquots to which DNA was added. Each PCR master mix was then divided into eight aliquots to which primer pairs were added resulting in primer pair $\times$ DNA arrays having 12 temperature gradient replications. Split-well technology resulted in PCR reactions in each well containing identical primer pairs but different DNA (H-19 and G421) such that gradient temperature variations were minimized in each paired comparison. PCR reactions were resolved on $2 \%$ agarose gels (Life Technologies) with ethidium bromide staining $\left(0.5 \mu \mathrm{g} \cdot \mathrm{mL}^{-1}\right)$, and visualized using a Dark Reader transilluminator coupled with a closed circuit digital (CCD) camera.

\section{Results and Discussion}

\section{Development of PCR markers based on simple sequence nucleotide repeats}

Digestion, SIZE FRACTIONATION AND PLASMID LIBRARY CON- 
Table 1. DNA sequences, optimal annealing temperatiure $\left({ }^{\circ} \mathrm{C}\right.$ ), and expected product size (EPS) (bp) for 110 SSR and two SCAR markers characterized in cucumber (Cucumis sativus L.).

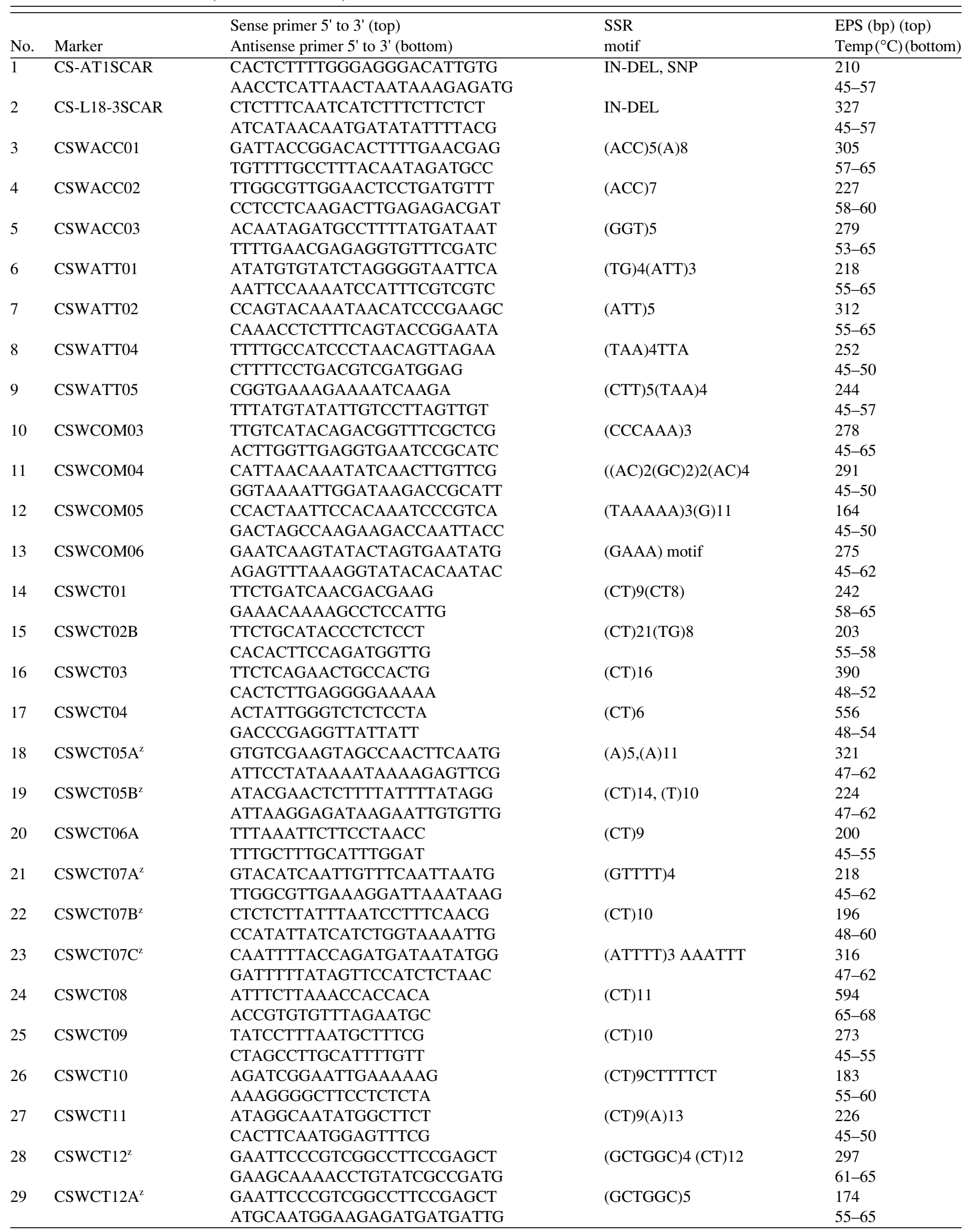


Table 1 (continued). DNA sequences, optimal annealing temperatiure $\left({ }^{\circ} \mathrm{C}\right)$, and expected product size (EPS) (bp) for $110 \mathrm{SSR}$ and two SCAR markers characterized in cucumber (Cucumis sativus L.).

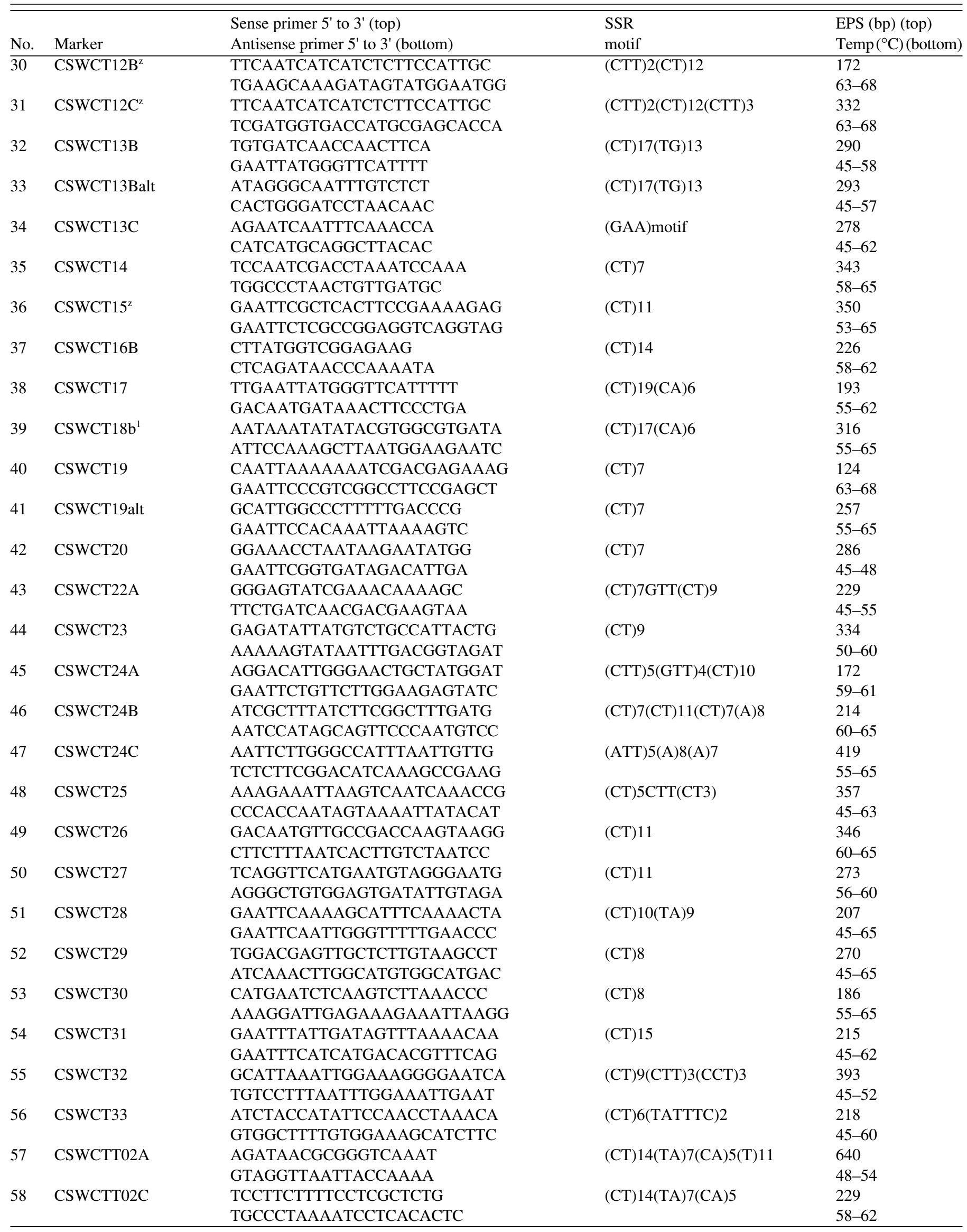




\begin{tabular}{|c|c|c|c|c|}
\hline No. & Marker & $\begin{array}{l}\text { Sense primer 5' to 3' (top) } \\
\text { Antisense primer 5' to 3' (bottom) }\end{array}$ & $\begin{array}{l}\text { SSR } \\
\text { motif }\end{array}$ & $\begin{array}{l}\text { EPS (bp) (top) } \\
\text { Temp }\left({ }^{\circ} \mathrm{C}\right) \text { (bottom) }\end{array}$ \\
\hline \multirow[t]{2}{*}{59} & CSWCTT02D & CATCCTCATTCATGGCGGAGTGTG & $(\mathrm{T}) 6,(\mathrm{~T}) 11,(\mathrm{CTT})$ motif & 246 \\
\hline & & GAATTTGTTAAAAATGTACATTAA & & $45-60$ \\
\hline \multirow[t]{2}{*}{60} & CSWCTT02D & САTCCTCATTCATGGCGGAGTGTG & $(\mathrm{T}) 6,(\mathrm{~T}) 11,(\mathrm{CTT})$ motif & 246 \\
\hline & & GAATTTGTTAAAAATGTACATTAA & & $45-60$ \\
\hline \multirow[t]{2}{*}{61} & CSWCTT03 & GCATATCGATTTAGGTCTAAT & $(\mathrm{CTT}) 4(\mathrm{~T}) 11$ & 184 \\
\hline & & GGATGGAGCGTCTCTTA & & $49-52$ \\
\hline \multirow[t]{2}{*}{62} & CSWCTT04 & GCGGAGATATGCCAATTTCAA & (CTT)4(A)13 & 231 \\
\hline & & TTCAAGCGCGACGACAAT & & $50-65$ \\
\hline \multirow[t]{2}{*}{63} & CSWCTT05 & AGTTAATGAGTGAATGTGCGAGTT & $(\mathrm{CTT}) 5$ & 424 \\
\hline & & GAATTCCGTTCATATGTGGGATAC & & $45-50$ \\
\hline \multirow[t]{2}{*}{64} & CSWCTT06 & TTTGAACTTTTTGATCCGCTTTTC & $(\mathrm{GTT}) 2(\mathrm{CTT}) 5(\mathrm{ATT}) 2$ & 423 \\
\hline & & CAGAAGGCGTGTATTAGCTTGATA & & $52-65$ \\
\hline \multirow[t]{2}{*}{65} & CSWCTT07 & TTGTTGCAGGCCAGTCTATACGGT & (CTT)6 & 275 \\
\hline & & GAATTCAAATCAAGGTAGCCGATG & & $54-65$ \\
\hline \multirow[t]{2}{*}{66} & CSWCTT08 & GATATAAGCGTTGTGAGGATATGC & (TAA)3(CTT)6 & 335 \\
\hline & & CGTGCTCTATGAAGTAAATTAGTA & & $55-65$ \\
\hline \multirow[t]{2}{*}{67} & CSWCTT09 & АААТTСТТТСССАТТСАТСААСТТ & $(\mathrm{CTT}) 5$ & 336 \\
\hline & & AAGCСТTCTTGTACСТCTCAATAG & & $45-50$ \\
\hline \multirow[t]{2}{*}{68} & CSWCTT10 & СТТСТСАССТСАААССССААТТТС & (CTT5) & 371 \\
\hline & & TGTTGACGCAGTTTAGCCGATTCT & & $52-55$ \\
\hline \multirow[t]{2}{*}{69} & CSWCTT11 & ACAAAGGGCAGGGACGTAGTCAAC & $(\mathrm{CT}) 6(\mathrm{CTT}) 4(\mathrm{CT}) 9$ & 382 \\
\hline & & AATTAACGAACCTGAACCGGAAAT & & $60-65$ \\
\hline \multirow[t]{2}{*}{70} & CSWCTT12 & CTGCTCCATCTTGAAAACATGCTG & (CTT)6 & 227 \\
\hline & & TATTACAGTTCGAGCAATTCTGCA & & $61-65$ \\
\hline \multirow[t]{2}{*}{71} & CSWCTT14 & AAAATATGAAACCCATGGACATGA & (GAA)9(TA)4 & 263 \\
\hline & & GATTAAATATTGGGAATTGCTAA & & $45-52$ \\
\hline \multirow[t]{2}{*}{72} & CSWGAAA01 & TTAGACTTTTATCTATGATTG & $(\mathrm{CT}) 4$ & 218 \\
\hline & & TTTATTTTATAACAGATTTCA & & $45-55$ \\
\hline \multirow[t]{2}{*}{73} & CSWGAAA02 & AGGGCGTGTGAAAATTTGATATAA & $(\mathrm{CTTT}) 8$ & 316 \\
\hline & & TTCGAGAGTGGAGGGCACTTTCGT & & $45-65$ \\
\hline \multirow[t]{2}{*}{74} & CSWGAAT01 & GTCGGCTTGTGAAGAGAGATTGTG & $(\mathrm{GAAT}) 5$ & 276 \\
\hline & & GTGGGCACTGGTCAGGCGTTGAGA & & $45-65$ \\
\hline 75 & CSWGAT01 & ACCCGTTCGTCTGTCTCT & $(\mathrm{CTT}) 4$ & 235 \\
\hline & & CCGACCTCTAGGGGATAA & & $45-55$ \\
\hline 76 & CSWGATT01A & ATTCAAGCAGTTTCTTTGAAAAGA & (A) $12,(\mathrm{GA}) 10$ & 377 \\
\hline & & CAGAATTGCTTGTTGCTGATGACT & & $55-68$ \\
\hline 77 & CSWGATT01B & TATCAGACGATCTCCATCCAGCAG & $(\mathrm{GA}) 10$ & 181 \\
\hline & & CAGAATTGCTTGTTGCTGATGACT & & $65-68$ \\
\hline 78 & CSWGATT01C & TATTGAAACAGAAATTAACATTGG & $(\mathrm{GAA}) 10$ & 155 \\
\hline & & TCTTATCCACATTCCATTAAGAAG & & $55-68$ \\
\hline 79 & CSWGATT01E & GTGCAATATGCATTTCTTC & (GGGTC)3, (AGCCC)3 & 235 \\
\hline & & GAATTCCAAAGTTGGAGAAAG & & $55-68$ \\
\hline 80 & CSWGCA01 & AGTGATGGTGCAGGGCTATCTTAT & $(\mathrm{GCA}) 8$ & 235 \\
\hline & & TTGTCTTCCCTCCTCTTCTCGTCT & & $55-65$ \\
\hline 81 & CSWGTA01 & TGTATGAATGTTTCTTACAAG & (GTA)5, (GAAA) motif & 172 \\
\hline & & AGGGTTTTATGTATTTGCATG & & $45-60$ \\
\hline 82 & CSWTA01 & ААСАТТСТСТАТАААСАТСТT & (TA)7 & 254 \\
\hline & & GGTTTCCCTAATGATATAA & & $45-52$ \\
\hline 83 & CSWTA03 & ATTGTGATTATCATGGGAGCTATA & (TA) 10 (TA) 20 & 413 \\
\hline & & AAACCAAGAATGATTTGTAATATG & & $51-54$ \\
\hline 84 & CSWTA04 & TAAACATATGTGATTATACAGCAA & (A) $11(\mathrm{TA}) 10$ & 314 \\
\hline & & GTGTTTTGGTGTTATGTGAATATC & & $57-60$ \\
\hline 85 & CSWTA05 & GCATGAGCTCGAGCTGGTGTAGTG & (TA) 12 & 278 \\
\hline & & CGCCTGTTTTCATTTTGATTGGTT & & $55-65$ \\
\hline 86 & CSWTA06 & GAATTTTAAATTTTTATGGGTCAT & (TA)7(TA) 16 & 292 \\
\hline & & AAACTTACCACTGGGGTGTAAATG & & $45-65$ \\
\hline 87 & CSWTA07 & TGCGATTTGAGACCACCTATTGAT & (TA)4(TA)7 & 355 \\
\hline & & AAACAGGGACATAGCATGGATCTA & & $53-65$ \\
\hline 88 & CSWTA08A & AAAGTGCGGGACTCACGCTTAATA & (T)8(A)13(TA) 6 & 347 \\
\hline & & CAGTAGCTTTTTATAGTACCTAAC & & $45-60$ \\
\hline
\end{tabular}


Table 1 (continued). DNA sequences, optimal annealing temperatiure $\left({ }^{\circ} \mathrm{C}\right)$, and expected product size (EPS) (bp) for $110 \mathrm{SSR}$ and two SCAR markers characterized in cucumber (Cucumis sativus L.).

\begin{tabular}{|c|c|c|c|c|}
\hline No. & Marker & $\begin{array}{l}\text { Sense primer 5' to } 3^{\prime} \text { (top) } \\
\text { Antisense primer 5' to } 3^{\prime} \text { (bottom) }\end{array}$ & $\begin{array}{l}\text { SSR } \\
\text { motif }\end{array}$ & $\begin{array}{l}\text { EPS (bp) (top) } \\
\text { Temp }{ }^{\circ} \mathrm{C} \text { (bottom) }\end{array}$ \\
\hline \multirow[t]{2}{*}{$\overline{89}$} & CSWTA08B & TTGCATTAATGCTATAAACTTACC & (T)7(TA)7 IN-DEL & 630 \\
\hline & & GAAATTAATATTTAGGCATTG & & $54-56$ \\
\hline \multirow[t]{2}{*}{90} & CSWTA08C & TAATATTGCATTAATGCTATAAAC & (T)7(TA)7 & 556 \\
\hline & & TCCTTAATTTCCCGCAATGCCTAA & & $53-65$ \\
\hline 91 & CSWTA09 & СТАСААААССТСТСАТТССТТАТТ & (TA)4(TG)3(TA)6 & 246 \\
\hline 92 & & ACTCACTGATCAATCATCCAGAGA & & $55-65$ \\
\hline \multirow[t]{2}{*}{93} & CSWTA11B & GGTAGGCAATCAAAGAGTGGATGG & (TA) $10(\mathrm{CA}) 7(\mathrm{TA} 5)$ & 390 \\
\hline & & AACATATAGGAATCTAACAAAGTG & & $53-60$ \\
\hline \multirow[t]{2}{*}{94} & CSWTA11C & GTTAAAGTATAAGTATAGTCTCCC & $(\mathrm{TA}) 8$ & 564 \\
\hline & & ACTTCCACTTCTCGCTTGACTCTC & & $45-56$ \\
\hline 95 & CSWTA13 & AGATGGGCAGTTAGAGTTGATGCT & (TA)8 (GGTT)4 & 303 \\
\hline 97 & & AATTCCTTTTCTTGTTCTTGTGTC & & $47-65$ \\
\hline \multirow[t]{2}{*}{98} & CSWTA16 & TTATCAACCCTTCGTTTGCAAGTT & (TA)6,(TA)3 & 332 \\
\hline & & CATTGCCATTCAAGCAAGTGATTC & & $45-60$ \\
\hline \multirow[t]{2}{*}{99} & CSWTA17 & CTTTGATGAGACTTCTAATCCCAA & (TA)6(CTT)3(TA)6(T)11 & 198 \\
\hline & & CCATGATTCAAGAAGATCAAATGA & & $45-60$ \\
\hline \multirow[t]{2}{*}{100} & CSWTAAA01 & CAATGCCTCAATCTGATAGGAATG & $($ TAAA) 4 & 306 \\
\hline & & ACTGGCTCTCTACATATTGTGAGG & & $57-65$ \\
\hline \multirow[t]{2}{*}{101} & CSWTG01 & ATTGTCTGATTCGGGTATG & (TG)5 & 178 \\
\hline & & GGCAGCAAGAGCACTACC & & $45-65$ \\
\hline \multirow[t]{2}{*}{102} & CSWTG02 & CTTTTGGACCGTTTTTGG & (TG)3-(TG)4 & 240 \\
\hline & & AAGAACCGCTCGGAGATG & & $58-65$ \\
\hline 104 & & ATTTCAAAATTAAAAAATATCAAC & & $68-72$ \\
\hline \multirow[t]{2}{*}{105} & CSWTG08 & ATTCAACATGCGTGCGTTCGTGCG & (TG)5N3(TG)4(TGCG)5 & 246 \\
\hline & & AATATCAACTTGTTCGATATCTTT & & $45-65$ \\
\hline \multirow[t]{2}{*}{106} & CSWTG09 & GAAGATACATAAATGTAGAAATGA & (TA) $5(\mathrm{CA}) 11$ & 262 \\
\hline & & CCGCAATGAATAAGATCCAACACA & & $45-60$ \\
\hline 107 & CSWTG10 & TCTTATGACAAAGAGTGTGGGTGG & (TGGG)2(TG)9 & 252 \\
\hline & & TTCACTTCACATGCGCATGCACAC & & $68-72$ \\
\hline 108 & CSWTGCG01 & CAACATGCGTGCGTTCGTGCGTTT & (TG)6(TG)4(TGCG)6 & 216 \\
\hline & & TCAAAATAATATTAATGGCTTGAA & & $64-71$ \\
\hline 109 & CSWTT01 & CTTGGCGCGACCTAC & $(\mathrm{CT}) 7$ & 372 \\
\hline & & GTAAGCGCGAGTCATCAG & & $55-60$ \\
\hline 110 & CSWTT02 & ATTTTTGCTCTGCGATGT & $(\mathrm{CT}) 4(\mathrm{~T}) 6$ & 193 \\
\hline & & АATTCTCCAAGCGTCCTT & & $45-65$ \\
\hline 111 & N6-1RTRANS & TCTATGATTTTCAACAATTGGAAG & Retrotransposon & $45-60$ \\
\hline & & GGTTTTCTTAAATAGAAGAACACC & 5 flanking region & \\
\hline & & AAACAATTTTCCAGATTCCACAGC & 3' flanking region & \\
\hline 112 & L18-2 H19A & CCATCATAGTCAAATAAGAAATGA & SNP & $50-65$ \\
\hline & & GGTAGATATGTGTGCGCTATTTTG & & \\
\hline
\end{tabular}

${ }^{2}$ Primer redesign based on emprical results from previous primer sets. 
STRUCTION. Agarose gel analysis of digested (EcoRI* and AcsI) G-421 DNA revealed distinct bright bands about 200 bp, 400 bp, and $600 \mathrm{bp}$ in length. These bands belong to two cucumber satellite DNA families (Type I and Type II), which consist of repeated units $\approx 180 \mathrm{bp}$ in size having one restriction site sequence for both AcsI and EcoRI* digests (Ganal et al., 1986). These highly repetitive satellite DNA families represent about $20 \%$ to $30 \%$ of the total nuclear DNA in cucumber.

The DNA was digested with Acs I (4 bp recognition site) and EcoR I* (4 to 5 bp recognition site) to 1) match the EcoR I ligation sites of the Lambda ZipLox arms for library construction and 2) increase the number of restrictions when compared to EcoR I. Digestion, thus, decreased the average fragment size in the digest to simplify the sequencing process. Size fractionation of restriction digests resulted in the separation of digests into 28 size pools $(0.1$ to $20 \mathrm{~kb})$. Agarose gel analysis showed that the 200,400 , and $600 \mathrm{bp}$ size pools contained bright DNA bands, which were later identified as Type I and II cucumber satellite DNA. The products of both restriction digests (ranging 200 to $1200 \mathrm{bp}$ ) were used in ligations leading to the construction of the genomic libraries used for the microsatellite capture. The inclusion of the 200,400 , and $600 \mathrm{bp}$ products in the ligation pool created a representational bias in the library toward satellite DNA sequences.

Sequencing and characterization of 355 clones derived from the (CT)12 GeneTrapper capture revealed numerous chimeric plasmid inserts (where at least one of the sequences was a Type I or Type II satellite DNA), and numerous single insertion events of Type I and Type II satellite DNA sequences. Similar results were obtained with the (CA) 12 and the (CTT) 8 captures. Therefore, the representational bias documented during restriction analysis was present in the library and ultimately in captured clones that contained putative microsatellite sequences. This indicates that the attempt to increase representation of the cucumber genome in digested products ranging between 200 to $1200 \mathrm{bp}$ decreased the effectiveness of the capture by increasing the presence of repetitive DNA in the library.

Microsatellite capture. The capture experiment used a biotinylated (CT) 12 oligonucleotide to probe genomic libraries and identify clones containing (CT)n microsatellites. As identified by PCR, this capture yielded 457 colonies harboring plasmids with positive insertional events. Characterization of plasmid inserts through PCR amplification with standard M13 forward and reverse primers, and a (CT) 12 primer revealed that $65 \%$ (297/457) of the clones were redundant (i.e., more than one clone per insert). Further characterization of 312 clones from the first capture by sequence analysis revealed three sources for the redundancy observed in the first capture. First, the capture hybridization step of the GeneTrapper protocol was more efficient in retaining plasmids with microsatellites having relatively long motifs $(>24 \mathrm{bp})$ that matched or exceeded the length of the biotinylated capture oligonucleotide ( 24 to $26 \mathrm{bp}$ ) than plasmids with shorter microsatellite motifs $(<24 \mathrm{bp})$. Thus, a specific sequence containing a (CT) 17 repeat would be more prevalent in redundant clones than a sequence containing a (CT) 9 repeat. Second, the rescue following transformation called for the incubation of electroporation products in SOC media for $>60 \mathrm{~min}$ allowing for one to two cell divisions in DH10B E. coli cells. This time interval may have resulted in the duplication to quadruplication of a single capture product. This hypothesis is supported by the fact that in a second capture experiment using the same library and oligonucleotide where the incubation time was shortened to 25 min, redundancy was reduced from $65 \%$ to $10 \%$. Last, single- stranded contaminants which were not eliminated during washing steps after the streptavidin capture were likely retained in the final solution used to electroporate competent cells. Given the representational bias of Type I and Type II satellite DNA in genomic libraries, this satellite DNA was likely also represented in the captured clones. Moreover, the redundancy of clone sequences was observed in subsequent captures (data not presented).

The application of the GeneTrapper system made it possible to isolate and characterize several cucumber microsatellite loci in a relatively short time without the use of radiolabeled products. This GeneTrapper protocol first described by Fazio and Staub (2000) in a preliminary report was also used to isolate sequences containing tandem repeats in a catfish (Ictalurus punctatus) brain cDNA library (Nonneman et al., 2001) where a redundancy of only $30 \%$ was observed. This capture reportedly yielded $64 \%$ (299/467) nonredundant clones, all containing microsatellites. Their experiments yielded a higher number of microsatellite containing clones (299) than what was obtained in the capture of cucumber microsatellites. This difference is likely due to efforts to increase genome representation in the 200 to $1200 \mathrm{bp}$ range, which consequently decreases efficiency in cucumber. Future attempts to use this methodology should take into consideration the presence of repetitive sequences when constructing a genomic library.

The capture and identification protocol described herein was used to develop 110 microsatellite markers (Table 1). Of these markers, 58 (52\%) contain dinucleotide repeats (CT, CA, TA), 21 (19\%) possess trinucleotide repeats (CTT, ATT, ACC, GCA), 3 (2.7\%) contain tetranucleotide repeats (TGCG, TTAA, TAAA), $4(3.6 \%)$ enclose pentanucleotide repeat (ATTTT, GTTTT, GGGTC, AGCCC), 3 (2.7\%) contain hexanucleotide repeats (CCCAAA, TAAAAA, GCTGGC), and 21 possess composite repeats. All primers amplified the expected product and were subjected to ATG-PCR to identify optimized conditions for PCR.

OPTIMIZATION OF PRIMER-PAIR-SPECIFIC PCR CONDITIONS. The potential of microsatellites and other PCR based markers in high throughput applications has been widely discussed (Donini et al., 1998; Gupta and Varshney, 2000; Powell et al., 1996). Multiplexing (i.e., the addition of multiple markers in a single PCR amplification) has been successfully used for parentage testing in goats (Capra hircus L. Bovidae) using two multiplex systems, each containing 11 microsatellite loci (Luikart et al., 1999). Multiplexing has also been used in several plant species including wheat (Triticum ssp.) (Donini et al., 1998; Gupta et al., 1999), apple (Malus $\times$ domestica Borkh.) (Hokanson et al., 1998), and grape (Vitis ssp.) (Lamboy and Alpha, 1998). However technical problems can arise during multiplexing. Donini et al. (1998) reported that multiplex PCR was very dependent on the choice of primer combinations and seldom produced amplifications as consistently as when primer pairs were used individually, and that background (nonspecific) amplification was common to many primer pairs, thus hindering the use of multiplex PCR. Furthermore, preferential amplification of smaller alleles over larger alleles as well as the variable plus A modification (nontemplated adenylation of the 3' end of the amplified sequence by Taq polymerase) resulted in misidentification of certain rainbow trout genotypes (Oncorhynchus mykiss, Salmonidae, Walbaum 1792) (Fishback et al., 1999). During PCR each primer pair may yield several products depending on reaction conditions (i.e., PCR mix, thermal cycler, and cycling conditions) (Staub et al., 1996a), and the nature of the DNA region that is being amplified (i.e., repeated 


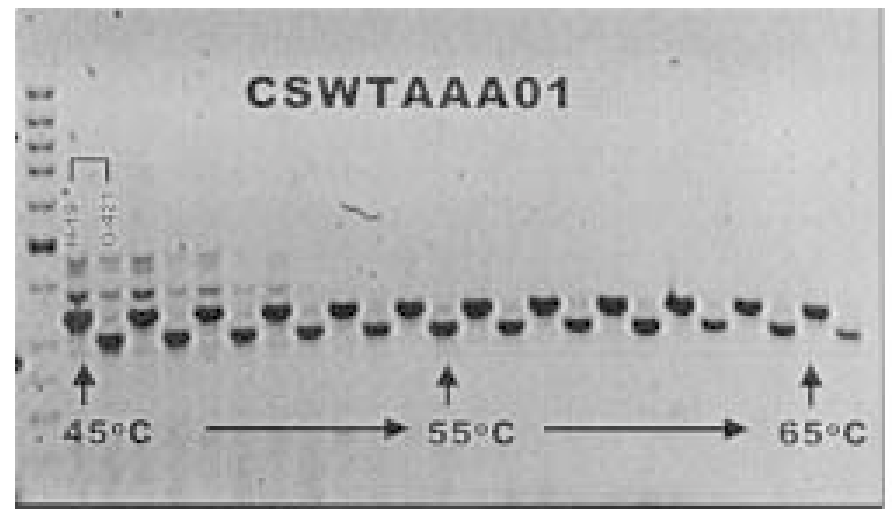

Fig. 2. Annealing temperature gradient (ATG) profile of CSWTAAA01 SSR marker using DNA of cucumber lines H-19 and G421 alternating in paired comparison. Lane 1 contains a 100-bp ladder and annealing temperature increases from $45^{\circ} \mathrm{C}$ (far left) to $65^{\circ} \mathrm{C}$ far right with a step of $1.8^{\circ} \mathrm{C}$ every two wells.

or unique) (Paglia and Morgante, 1998). Primer-pair characteristics may be such that they hinder PCR (i.e., reaction kinetics) resulting in inadequate resolution of predicted multiplexed primer products.

This and other problems associated with multiplexing reactions (i.e., reaction optimization) could result in inconsistent and

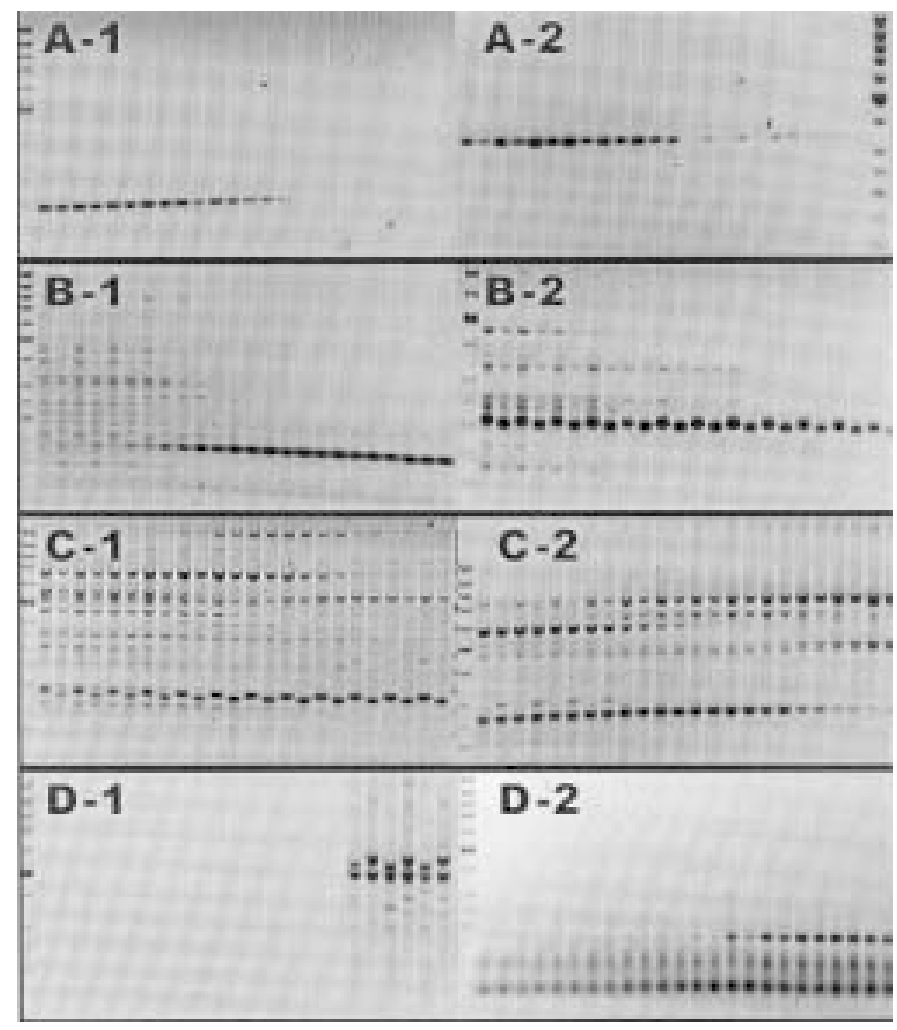

Fig. 3. Types of annealing temperature gradient (ATG) profiles observed in 214 simple sequence repeat (SSR) and sequence characterized amplified regions (SCAR) cucumber marker optimization experiments (Panels A-D). (A) Amplification of a single PCR product; (B) amplification of multiple PCR products at lower temperatures and of a single product at higher temperatures; (C) amplification of multiple PCR products across the gradient; (D) amplification of single or multiple PCR products only at higher temperatures. Lane 1 contains a 100-bp ladder, and remaining lanes contain paired DNA of lines H-19 and G421 which underwent PCR in ascending $1.8^{\circ} \mathrm{C}$ intervals from 45 to $65^{\circ} \mathrm{C}$. A1, A2, B1, B2, C1, C2, D1, and D2 represent results from different sets of SSR primers. inefficient implementation of this PCR application where equipment and reagents are not standardized. Implementation difficulties may be minimized by performing ATG-PCR profiling for each primer using standard DNA preparations (Fig. 2). The application of ATG-PCR as a preparatory step to PCR, assists in reaction optimization by identifying low risk temperature dependent annealing regions in which only a single target amplicon is present after PCR. Thus, the ATG-PCR profiling of potential PCR-based markers such as those developed herein (Table 1) is necessary for their universal acceptance and utility.

Observation of 214 SSR primer-pair annealing temperature optimizations $\left(45\right.$ to $\left.65^{\circ} \mathrm{C}\right)$ using cucumber DNA (lines H-19 and G421) revealed four consistent visual band grouping types: 1) amplification of a single ATG-PCR product $\approx 25 \%$ of the primer pairs) (Fig. 3, panel A); 2) amplification of multiple products at lower temperatures and the presence of a single PCR product at higher temperatures $(\approx 40 \%$ of the primer pairs) (Fig. 3, panel B); 3) amplification of multiple PCR regardless of annealing temperature ( $\approx 25 \%$ of the primer pairs) (Fig. 3, panel C), and; 4) amplification of single or multiple PCR products only at relatively high temperatures $\left(\geq 60^{\circ} \mathrm{C} ; \approx 10 \%\right.$ of the primer pairs) (Fig. 3 , panel D).

These ATG-PCR profiling observations can be used to strategically multiplex SSR or SCAR primers, identify new polymorphisms, and avoid mislabeling of amplicons. For instance, ATGPCR profile outcome information can be used to group primer pairs to set optimized temperature conditions for singlet or multiplexed PCR. For multiplexing, markers of differing molecular weight can be grouped by optimal annealing temperature to increase the success of the PCR. Moreover, ATG-PCR profiling provides evidence of primer PCR temperature complexity that can be used by laboratories wishing to use particular markers. New polymorphisms were observed that were not expected based on primer ATG-PCR profiles (data not presented). These polymorphisms may be due to duplicated DNA regions in the cucumber genome.

\section{Development of PCR markers based on single nucleotide polymorphisms (SNP) and characterized sequences (SCAR)}

The conversion of randomly amplified targeted marker bands (RAPDs) to sequence specific PCR markers results in more stable markers (Staub et al., 1996c). Such conversion is often accomplished by cloning and sequencing polymorphic target bands. Resulting primers are designed specifically for a particular sequence (e.g., SCARS, STS) (Michelmore et al., 1991; Paran and Michelmore, 1993). This procedure was used in cucumber (Horejsi et al., 1999) in an attempt to convert 75 RAPD into SCAR

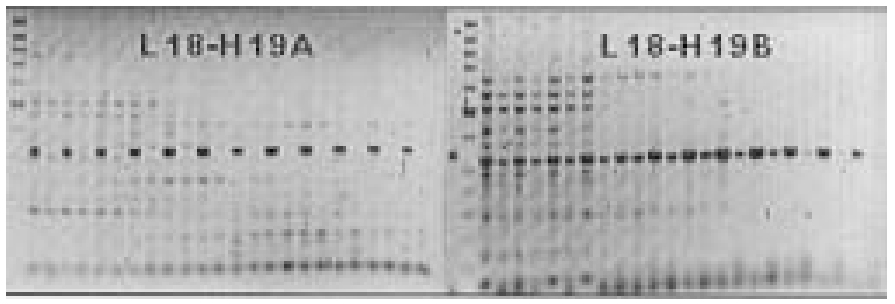

Fig. 4. Comparison of single nucleotide polymorphism (SNP) primers developed to differentiate cucumber lines H-19 and G421. Primers designed on a 5-bp polymorphism (L18-H19A) vs. a 2-bp polymorphism (L18-H19B). Lane 1 contains a 100-bp ladder, and the remaining lanes contain paired DNA of lines $\mathrm{H}-19$ and $\mathrm{G} 421$, which underwent PCR in ascending $1.8^{\circ} \mathrm{C}$ intervals from 45 to $65{ }^{\circ} \mathrm{C}$. 
markers. Conversion resulted in 48 (64\%) SCARs, in which 11 $(15 \%)$ retained their polymorphic nature.

Molecular markers tightly linked to economically important traits such as disease resistance, yield or quality are of particular importance to cucumber improvement programs. Given the low level of polymorphism in cucumber (3\% to $8 \%$ ), the problematic nature of RAPD markers (reproducibility across laboratories; Staub et al., 1996a), and the low percentage of RAPD to SCAR conversion (Horejsi et al., 1999), the identification and development of methodologically stable markers is of consequence. Moreover, concomitant assessment of ATG-PCR profiles of putatively useful PCR markers increases their potential implementation.

CONVERSION OF SCAR L18 ${ }_{600}$ TO AN SNP MARKER. The SCAR, $\mathrm{L}_{18} 8_{600}$, is of particular importance since it is associated (LOD 10.4) with quantitative trait loci (QTL) for multiple lateral branching (MLB), an important yield component trait in cucumber (Serquen et al., 1997). In contrast to its source RAPD, however, this marker was monomorphic with respect to the mapping parents H-19 and G421. Its RAPD counterpart is linked in repulsion phase to the MLB QTL limiting its usefulness in marker-assisted backcross selection. Sequencing of monomorphic L18 ${ }_{600}$ SCAR products in this study revealed several single nucleotide polymorphisms (SNPs) within the amplicon (data not presented). Consequently, both sense and antisense primers were designed so that the 3 ' end of the oligonucleotides matched only the SNP allele evident in H-19. Since alternative SNPs were identified, two unique markers (L18-2-H19A and L18-2-H19B) were created. Marker L18-2-H19A was designed on a five-base polymorphism (i.e., two-base identity, and two-base Indel in the forward primer and one-base identity in the reverse primer). Marker L18-2-H19B SNP was based on one-base polymorphisms in both forward and reverse primers. These primer constructions were examined by the ATG-PCR protocol (Fig. 4) to determine their reliability in differentiating $\mathrm{H}-19$ and G421 DNA, and to optimize reaction conditions. Results indicate that the SNP marker construction based on multiple polymorphisms (L18-2-H19A) was more reliable in a broad PCR temperature range than the marker based on a single base pair change (L18-2H19B) (data not presented). Thus, L-18-H19A was successfully used in marker-assisted selection and quantitative trait analysis experiments with cucumber (Fazio, 2001). Sequencing of RAPD bands L18-3 and AT1-2 resulted in the construction of two codominant SCAR markers, L18-3SCAR and AT1-2SCAR (Table $1)$.

Conversion of RAPD $\mathbf{N 6}_{200}$ To SCAR $\mathbf{N 6}_{200}$. The RAPD to SCAR conversion of a codominant RAPD product, $\mathrm{N6}_{800}$, resulted in the characterization of a SCAR marker designated SCAR N6 ${ }_{800}$ (Horejsi et al., 1999). Although this SCAR yielded different size bands in both H-19 (584 bp) and G421 (1046 bp), analysis of $\mathrm{F} \mathrm{F}_{2}$ mapping population (Fazio, 2001) revealed that this marker behaved in a dominant fashion exhibiting preferential amplification of the $584 \mathrm{bp}$ band in heterozygous individuals. An ATG-PCR profile of the original $\mathrm{N}_{800}$ SCAR primers revealed novel polymorphisms between $45{ }^{\circ} \mathrm{C}$ to $48{ }^{\circ} \mathrm{C}$. These were subsequently mapped (Fazio, 2001), and found to be distant (50 $\mathrm{cM}$ ) from the $\mathrm{N6}_{800}$ SCAR.

Given the size difference between the two $N 6_{800}$ alleles (462 bp), it is possible that competition in the PCR reaction caused the higher molecular weight band to be amplified less efficiently than its smaller weight counterpart in heterozygous DNA samples. Sequence analysis (data not presented) of both alleles revealed an insertion of a transposable element belonging to the SINE-like family of retrotransposons (Kumar and Bennetzen, 1999; Kunze et al., 1997). These elements share features with SINE and Alu sequences in mammals, and are characterized by flanking 14 to 15 bp target-site duplications (TSDs) and a GC rich region in the 5' half of the insert. The element from cucumber contains a 90-bp $\mathrm{GC}$ rich region in one of the termini as well as 17-bp long TSDs (data not presented). The GC rich region might have contributed to the failed amplification of the 1046-bp band of $\mathrm{N}_{800}$ SCAR marker in heterozygous individuals by raising the Tm requirement of the amplicon during PCR.

A strategy was used to convert this pseudodominant $\mathrm{N}_{800}$ SCAR marker into a codominant marker. Three primers were constructed resulting in a forward and reverse primer which amplified the putative nonretrotransposon allele and an additional reverse primer $30 \mathrm{bp}$ within the putative retrotransposon insertion further away from the $\mathrm{GC}$ rich region. Genetic analysis of these primers using an $\mathrm{F}_{2}$ population (H-19 $\times$ G421) demonstrated that the new SCAR marker (N6A-SCAR) segregated in a codominant fashion (Fazio, 2001). Sequences from plant retrotransposons elements have been used in Pisum species and conifers to construct PCR-based marker systems (Flavell et al., 1998; Pearce et al., 1999) for use in high throughput analysis. The development of markers based on retrotransposon sequences such as $\mathrm{N}_{800}$ will provide additional markers for genetic analysis in cucumber.

The application of molecular markers may increase the efficiency of plant breeding (Gupta and Varshney, 2000; Lande, 1990; Lee, 1995; Staub et al., 1996c; Young, 1999). Marker systems developed for the genetic analysis of cucumber have provided valuable information about genetic diversity (Dijkhuizen et al., 1996; Horejsi and Staub, 1999; Staub et al., 2002), have enhanced genetic map construction (Bradeen et al., 2001), and have been used in marker-assisted selection (Fazio, 2001). The level of polymorphism in a preliminary assessment of SSR variation between $C$. sativus var. sativus and var. hardwickii and among elite germplasm (European and U.S.) is $\approx 35 \%$ and $\approx 15 \%$, respectively (unpublished data). Thus, the addition of $110 \mathrm{SSR}$, 4 SCAR and 2 SNP markers to the array of previously identified markers will enhance the use of genetic markers in breeding, diversity analysis, variety identification, and in the protection of cucumber germplasm. Moreover, these markers will likely provide a means for greater integration of genetic information during mapping experiments in cucumber (e.g., map merging) and in elucidating synteny relationships between cucumber and melon (Cucumis melo L.).

\section{Literature Cited}

Anderson, B. and G. McDonald. 1993. Construction of DNA libraries of A-T rich organisms using EcoRI star activity. Anal. Biochem. 211:325327.

Bradeen, J.M., J.E. Staub, C. Wye, R. Antonise, and J. Peleman. 2001. Towards an expanded and integrated linkage map of cucumber (Cucumis sativus L.). Genome 44:111-119.

Breslauer, K., J.R. Frank, H. Blocker, and L.A. Marky. 1986. Predicting DNA duplex stability from the base sequence. Proc. Natl. Acad. Sci. USA 83:3746-3750.

Bryan, G.J., A.J. Collins, P. Stephenson, A. OrryJ, .B. Smith, and M.D. Gale. 1997. Isolation and characterisation of microsatellites from hexaploid bread wheat. Theor. Appl. Genet. 94:557-563.

Buteler, M.I., R.L. Jarret and D.R. LaBonte. 1999. Sequence characterization of microsatellites in diploid and polyploid Ipomoea. Theor. Appl. Genet. 99:123-132. 
Chavarriagaaguirre, P., M.M. Maya, M.W. Bonierbale, S. Kresovich, M.A. Fregene, J. Tohme, and G. Kochert. 1998. Microsatellites in cassava (Manihot Esculenta Crantz) - Discovery, inheritance and variability. Theor. Appl. Genet. 97:493-501.

Cipriani, G., G. Lot, W.G. Huang, M.T. Marrazzo, E. Peterlunger, and R. Testolin. 1999. AC/GT and AG/CT microsatellite repeats in peach [Prunus persica (L) Batsch]: Isolation, characterisation and crossspecies amplification in Prunus. Theor. Appl. Genet. 99:65-72.

Cregan, P.B., J. Mudge, E.W. Fickus, L.F. Marek, D. Danesh, R. Denny, R.C. Shoemaker, B.F. Matthews, T. Jarvik, and N.D. Young. 1999. Targeted isolation of simple sequence repeat markers through the use of bacterial artificial chromosomes. Theor. Appl. Genet. 98:919-928.

Danin Poleg, Y., N. Reis, S. Baudracco Arnas, M. Pitrat, J.E. Staub, M. Oliver, P. Arus, C.M. de Vicente, and N. Katzir. 2000. Simple sequence repeats in Cucumis mapping and map merging. Genome 43:963-974.

Danin Poleg, Y., N. Reis, G. Tzuri, and N. Katzir. 2001. Development and characterization of microsatellite markers in Cucumis. Theor. Appl. Genet. 102:61-72.

Dayanandan, S., O.P. Rajora, and K.S. Bawa. 1998. Isolation and characterization of microsatellites in trembling aspen (Populus tremuloides). Theor. Appl. Genet. 96:950-956.

Dijkhuizen, A., W.C. Kennard, M.J. Havey, and J.E. Staub. 1996. RFLP variation and genetic relationships in cultivated cucumber. Euphytica 90:79-87.

Donini, P., P. Stephenson, G.J. Bryan, and R.M.D. Koebner. 1998. The potential of microsatellites for high throughput genetic diversity assessment in wheat and barley. Genet. Res. Crop Evol. 45:415-421.

Fazio, G. 2001. Comparative study of marker-assisted and phenotypic selection and genetic analysis of yield components in cucumber. $\mathrm{PhD}$ diss. (diss. abstr. 3033308) Univ. Wis., Madison.

Fazio, G. and J.E. Staub. 2000. Method for the development and characterization of microsatellite markers in cucumber. Cucurbit Genet. Coop. Rpt. 23:4-7.

Fischer, D. and K. Bachmann. 1998. Microsatellite enrichment in organisms with large genomes (Allium cepa L.). Biotechniques 24:796.

Fishback, A.G., R.G. Danzmann, T. Sakamoto, and M.M. Ferguson. 1999. Optimization of semi-automated microsatellite multiplex polymerase chain reaction systems for rainbow trout (Oncorhynchus mykiss). Aquaculture 172:247-254.

Flavell, A.J., M.R. Knox, S.R. Pearce, and T.H.N. Ellis. 1998. Retrotransposon-based insertion polymorphisms (RBIP) for high throughput marker analysis. Plant J. 16:643-650.

Freier, S., M.R. Kierzek, J.A. Jaeger, N. Sugimoto, M.H. Caruthers, T. Neilson, and D.H. Turner. 1986. Improved free-energy parameters for predictions of RNA duplex stability. Proc. Nat. Acad. Sci. USA. 83:9373-9377.

Ganal, M., I. Riede, and V. Hemleben. 1986. Organization and sequence analysis of two related satellite DNAs in cucumber (Cucumis sativus L.). J. Mol. Evol. 23:23-30.

Gupta, P.K. and R.K. Varshney. 2000. The development and use of microsatellite markers for genetic analysis and plant breeding with emphasis on bread wheat. Euphytica 113:163-185.

Gupta, P.K., R.K. Varshney, P.C. Sharma, and B. Ramesh. 1999. Molecular markers and their applications in wheat breeding. Plant Breeding 118:369-390.

Hokanson, S.C., A.K. Szewc McFadden, W.F. Lamboy, and J.R. McFerson. 1998. Microsatellite (SSR) markers reveal genetic identities, genetic diversity and relationships in a Malus $\times$ domestica borkh. core subset collection. Theor. Appl. Genet. 97:671-683.

Horejsi, T., J.M. Box, and J.E. Staub. 1999. Efficiency of randomly amplified polymorphic DNA to sequence characterized amplified region marker conversion and their comparative polymerase chain reaction sensitivity in cucumber. J. Amer. Soc. Hort. Sci. 124:128-135.

Horejsi, T. and J.E. Staub. 1999. Genetic variation in cucumber (Cucumis sativus L.) as assessed by random amplified polymorphic DNA. Genet. Res. Crop Evol. 46:337-350.

Horejsi, T., J.E. Staub, and C. Thomas. 2000. Linkage of random amplified polymorphic DNA markers to downy mildew resistance in cucumber (Cucumis sativus L.). Euphytica 115:105-113.

Huang, W.G., G. Cipriani, M. Morgante, and R. Testolin. 1998. Microsatellite DNA in Actinidia chinensis: Isolation, characterisation, and homology in related species. Theor. Appl. Genet. 97:1269-1278.

Katzir, N., Y. Danin Poleg, G. Tzuri, Z. Karchi, U. Lavi, and P.B. Cregan. 1996. Length polymorphism and homologies of microsatellites in several Cucurbitaceae species. Theor. Appl. Genet. 93:1282-1290.

Kennard, W.C., K. Poetter, A. Dijkhuizen, V. Meglic, J.E. Staub, and M.J. Havey. 1994. Linkages among RFLP, RAPD, isozyme, diseaseresistance, and morphological markers in narrow and wide crosses of cucumber. Theor. Appl. Genet. 89:42-48.

Knapp, S.J. 1998. Marker-assisted selection as a strategy for increasing the probability of selecting superior genotypes. Crop Sci. 38:11641174

Knerr, L.D. and J.E. Staub. 1992. Inheritance and linkage relationships of isozyme loci in cucumber (Cucumis sativus L.). Theor. Appl. Genet. 84:217-224.

Knerr, L.D., J.E. Staub, D.J. Holder, and B.P. May. 1989. Genetic diversity in Cucumis sativus L. assessed by variation at 18 allozyme coding loci. Theor. Appl. Genet. 78:119-128.

Kumar, A. and J. Bennetzen. 1999. Plant retrotransposons. Annu. Rev. Genet. 33:479-532.

Kunze, R., H. Saedler, and W.E. Lonnig. 1997. Plant transposable elements. Adv. Bot. Res. 27:331-470.

Lamboy, W.F. and C.G. Alpha. 1998. Using simple sequence repeats (SSRs) for DNA fingerprinting germplasm accessions of grape (Vitis L.) species. J. Amer. Soc. Hort. Sci. 123:182-188.

Lande, R. 1990. Marker-assisted selection in relation to traditional methods of plant breeding, p. 437-451. In: Plant breeding in the 1990s. Proc. Symp. Plant Breeding in the 1990s, Raleigh, N.C.

Lee, M. 1995. DNA markers and plant breeding programs. Adv. Agron. 35:265-344.

Litt, M. and J.A. Luty. 1989. A hypervariable microsatellite revealed by in vitro amplification of a dinucleotide repeat within the cardiac muscle actin gene. Amer. J. Hum. Genet. 44:397-401.

Luikart, G.M., P. Biju Duval, O. Ertugrul, Y. Zagdsuren, C. Maudetand, and P. Taberlet. 1999. Power of 22 microsatellite markers in fluorescent multiplexes for parentage testing in goats (Capra hircus). Animal Genet. 30:431-438.

Meglic, V. and J.E. Staub. 1996a. Genetic diversity in cucumber (Cucumis sativus L). II. an evaluation of selected cultivars released between 1846 and 1978. Genet. Res. Crop Evol. 43:547-558.

Meglic, V. and J.E. Staub. 1996b. Inheritance and linkage relationships of isozyme and morphological loci in cucumber (Cucumis Sativus L). Theor Appl. Genet. 92:865-872.

Michelmore, R.W., I. Paran, and R.V. Kesseli. 1991. Identification of markers linked to disease-resistance genes by bulked segregant analysis: A rapid method to detect markers in specific genomic regions by using segregating populations. Proc. Natl. Acad. Sci. USA 88:98289832.

Nonneman, D.J., G.C. Waldbieser, and W.R. Wolters. 2001. Abundance of microsatellite containing clones in a channel catfish (Ictalurus punctatus) brain cDNA library. Plant and Animal Genome IX, San Diego, Calif.

Oetting, W.S., H.K. Lee, D.J. Flanders, G.L. Wiesner, T.A. Sellers, and R.A. King. 1995. Linkage analysis with multiplexed short tandem repeat polymorphisms using infrared fluorescence and M13 tailed primers. Genomics 30:450-458.

Paetkau, D. 1999. Microsatellites obtained using strand extension: An enrichment protocol. Biotechniques 26:690.

Paglia, G. and M. Morgante. 1998. PCR-based multiplex DNA fingerprinting techniques for the analysis of conifer genomes. Mol. Breeding 4:173-177.

Paran, I. and R.W. Michelmore. 1993. Development of reliable PCRbased markers linked to downy mildew resistance genes in lettuce. Theor. Appl. Genet. 85:985-993.

Pearce, S.R., C. Stuart-Rogers, M.R. Knox, A. Kumar, T.H.N. Ellis, and A.J. Flavell. 1999. Rapid isolation of plant Ty1-copia group 
retrotransposon LTR sequences for molecular marker studies. Plant J. 19:711-717.

Powell, W., M. Morgante, C. Andre, M. HanafeyJ.-Vogel, S. Tingey, and A. Rafalski. 1996. The comparison of RFLP, RAPD, AFLP and SSR (microsatellite) markers for germplasm analysis. Mol Breeding 2:225-238.

Quarrie, S.A. 1996. New molecular tools to improve the efficiency of breeding for increased drought resistance. Plant Growth Regulat. 20:167-178.

Robinson, C.R. and S.G. Sligar. 1995. Heterogeneity in molecular recognition by restriction endonucleases: Osmotic and hydrostatic pressure effects on BamHI, PvuII, and EcoRV specificity. Proc. Natl. Acad. Sci. USA 92:3444-3448.

Roder, M.S., V. Korzun, K. Wendehake, J. Plaschke, M.H. Tixier, P. Leroy, and M.W. Ganal. 1998. A microsatellite map of wheat. Genetics 149:2007-2023.

Romagosa, I., F. Han, S.E. Ullrich, P.M. Hayes, and D.M. Wesenberg. 1999. Verification of yield QTL through realized molecular markerassisted selection responses in a barley cross. Mol. Breeding 5:143-152.

Rychlik, W. and R.E. Rhoads. 1989. A computer program for choosing optimal oligonucleotides for filter hybridization, sequencing and in vitro amplification of DNA. Nucleic Acids Res. 17:8543-8552.

Rychlik, W., W.J. Spencer, and R.E. Rhoads. 1990. Optimization of the annealing temperature for DNA amplification in vitro. Nucleic Acids Res. 18:6409-6412.

Saiki, R.K., D.H. Gelfand, S. Stoffel, S.J. Scharf, R. Higuchi, G.T. Horn, K.-B. Mullis, and H.A. Erlich. 1988. Primer-directed enzymatic amplification of DNA with a thermostable DNA polymerase. Science 239:487-491.

Sambrook, J., E.F. Fritsch, and T. Maniatis. 1989. Molecular cloning: A laboratory manual. Cold Spring Harbor Laboratory Press, Cold Spring Harbor, N.Y.

Serquen, F.C., J. Bacher, and J.E. Staub. 1997. Mapping and QTL analysis of horticultural traits in a narrow cross in cucumber (Cucumis sativus L.) using random-amplified polymorphic DNA markers. Mol Breeding 3:257-268.
Shen, L., B. Courtois, K.L. McNally, S. Robin, and Z. Li. 2001. Evaluation of near isogenic lines of rice introgressed with QTLs for root depth through marker-aided selection. Theor. Appl. Genet. 103:7583.

Staub, J.E. and V. Meglic. 1993. Molecular genetic markers and their legal relevance for cultivar discrimination: A case study in cucumber. HortTechnology 3:291-300.

Staub, J.E., J. Bacher, and K. Poetter. 1996a. Sources of potential errors in the application of random amplified polymorphic DNAs in cucumber. HortScience 31:262-266.

Staub, J.E., A. Gabert, and T.C. Wehner. 1996b. Plant variety protection: A consideration of genetic relationships. HortScience 31:1086-1091.

Staub, J.E., F.C. Serquen, and M. Gupta. 1996c. Genetic markers, map construction, and their application in plant breeding. HortScience 31:729-741.

Staub, J.E. 1999. Intellectual property rights, genetic markers, and hybrid seed production. J New Seeds. 1:39-64.

Staub, J.E., F. Dane, K. Reitsma, G. Fazio, and A. Lopez-Sese. 2002. The formation of test arrays and a core collection in cucumber using phenotypic and molecular marker data. J. Amer. Soc. Hort. Sci. 127(4):558-567.

Tanksley, S.D. and J.C. Nelson. 1996. Advanced backcross QTL analysis-A method for the simultaneous discovery and transfer of valuable Qtls from unadapted germplasm into elite breeding lines. Theor. Appl. Genet. 92:191-203.

University of Arkansas-Fayetteville. 1993.H-19 cucumber plant variety Protection certificate, PVP no. 8900073. USDA-Agr. Mktg. Serv., Wash., D.C.

Young, N.D. 1999. A cautiously optimistic vision for marker-assisted breeding. Mol Breeding 5:505-510.

Yousef, G.G. and J.A. Juvik. 2001. Comparison of phenotypic and marker assisted-selection for quantitative traits in sweet corn. Crop Sci. 41:645-655.

Yu, K.F., S.J. Park, and V. Poysa. 1999. Abundance and variation of microsatellite DNA sequences in beans (Phaseolus and Vigna). Genome 42:27-34. 